\title{
Dogs as a source of Salmonella spp. in apparently healthy dogs in the Valencia Region. Could it be related with intestinal lactic acid bacteria?
}

\author{
E. Bataller ${ }^{1 *}$, E. García-Romero², L. Llobat ${ }^{1}$, V. Lizana ${ }^{3,4}$ and E. Jiménez-Trigos ${ }^{1 *}$
}

\begin{abstract}
Background: Although salmonellosis is considered one of the most important food-borne zoonotic diseases in Europe, close contact between dogs and their owners can also be a potential source of Salmonella spp. for humans. This study assessed the prevalence and antimicrobial resistance of Salmonella spp. in apparently healthy dogs in the Valencian Region, eastern Spain. Moreover, a macroscopic comparison of lactic acid bacteria in both Salmonella-positive and Salmonella-negative dogs was carried out.

Results: Of a total of 325 dogs sampled, 6 (1.85\%) were positive for Salmonella spp. with 3 different serotypes, Havana (3), Mikawasima (2) and monophasic Typhimurium (1). All isolates were susceptible to all antimicrobials tested except monophasic $S$. Typhimurium, which was resistant to ampicillin. Finally, macroscopic results revealed that lactic acid bacteria had higher heterogeneity in the Salmonella-negative dogs than in the Salmonella-positive dogs. Although the results in our study showed a low prevalence of Salmonella spp., raw food has been suggested as a risk factor for bacteria in dog faeces.

Conclusions: Public awareness campaigns on good hygiene practices, especially after handling canine faeces or raw food, are necessary. Furthermore, to reduce the potential transmission of bacteria, dogs should be fed food that has been properly cooked, as raw or undercooked food can be a source of zoonotic pathogens. Moreover, further studies must be performed to determine the relationship between lactic acid bacteria and Salmonella spp. in dog faeces.
\end{abstract}

Keywords: Salmonella, Dog, Prevalence, Zoonosis, Risk factors, Raw food

\section{Background}

Salmonellosis is considered one of the most important foodborne zoonotic diseases in Europe [1]. In 2017, 91, 662 confirmed human salmonellosis cases were reported by all state members in the EU, and eggs, egg products,

\footnotetext{
* Correspondence: esther.bataller@uchceu.es; estrella.jimenez@uchceu.es ${ }^{1}$ Research Group Microbiological Agents Associated with Animal Reproduction (PROVAGINBIO), Department of Animal Production and Health, Veterinary Public Health and Food Science and Technology (PASAPTA), Facultad de Veterinaria, Universidad Cardenal Herrera-CEU, CEU Universities, Carrer Tirant lo Blanc 7, 46115 Alfara del Patriarca, València, Spain Full list of author information is available at the end of the article
}

meat and meat products contaminated with bacteria were the main sources of human infection [1]. However, companion animals can also be a source of Salmonella spp. for humans [2-6].

Dogs are one of the most important companion animals in the world [7]. It has been estimated that in Spain, there are more than 7 million pet dogs [8]. Close contact between dogs and humans has been recognized as a potential source of Salmonella spp. zoonotic infection [2, 4, 9-11]. In fact, the most frequent serotypes isolated from human gastroenteritis cases correspond

(c) The Author(s). 2020 Open Access This article is licensed under a Creative Commons Attribution 4.0 International License, which permits use, sharing, adaptation, distribution and reproduction in any medium or format, as long as you give appropriate credit to the original author(s) and the source, provide a link to the Creative Commons licence, and indicate if changes were made. The images or other third party material in this article are included in the article's Creative Commons licence, unless indicated otherwise in a credit line to the material. If material is not included in the article's Creative Commons licence and your intended use is not permitted by statutory regulation or exceeds the permitted use, you will need to obtain permission directly from the copyright holder. To view a copy of this licence, visit http://creativecommons.org/licenses/by/4.0/. The Creative Commons Public Domain Dedication waiver (http://creativecommons.org/publicdomain/zero/1.0/) applies to the data made available in this article, unless otherwise stated in a credit line to the data. 
with more prevalent serotypes in dogs [11, 12]. In addition, companion animals could be an important source of multidrug-resistant Salmonella spp. [13]. Therefore, pet dogs should be considered a public health risk [4]. Children, elderly and immunocompromised individuals have a higher risk of salmonellosis because they are more susceptible to infection $[2,11,14,15]$.

Since the 1970s, previous studies have reported the zoonotic transmission of Salmonella spp. from dogs [16]. Nevertheless, the prevalence of this bacterium in dogs varies considerably. First, dogs usually act as asymptomatic carriers, and they can shed one or more serotypes intermittently for more than 6 weeks $[11,17]$. Moreover, dogs can harbour Salmonella spp. in the intestine and mesenteric lymph nodes without evidence of clinical signs $[10,11,18]$. Different studies have shown a wide prevalence of Salmonella spp. that oscillates between 0 and $79 \%$ [11, 12, 18-25]. This variability makes establishing the real prevalence among dog populations a challenge.

Other factors that have been reported to influence the prevalence of Salmonella spp. in dogs are the environment where animals live or contact with wild animals or other infected animals [11, 18, 26]. Additionally, animal feeding has been described as one of the main risk factors for the prevalence of Salmonella spp. in dogs [11]. Feeding dogs with raw food has also been related to the high prevalence of salmonellosis [12, 20, 21, 27, 28].

Another factor related to the increase in Salmonella spp. in animals could be associated with the alteration of normal microbiota, which protects the gastrointestinal tract from colonization by pathogens; alterations in the normal microbiota could provide a suitable environment for bacterial replication $[29,30]$.

As mentioned above, the prevalence of Salmonella serotypes in clinically healthy dogs varies notably and may even be different depending on the country [11]. As far as we know, no studies on the prevalence of Salmonella spp. in dogs have been performed in Spain. Therefore, the objective of this study was to determine the presence of Salmonella spp. in asymptomatic dogs housed in different environmental conditions in the Valencian Region (southern Spain). Moreover, the antimicrobial drug susceptibility of the isolates was determined, and macroscopic analysis of gastrointestinal lactic acid bacteria (LAB) in Salmonella spp.-positive and Salmonella spp.negative animals was also evaluated.

\section{Results}

The prevalence of Salmonella spp. in apparently healthy dogs

The number of dogs sampled and the prevalence of Salmonella spp. is shown in Table 1. A total of 325 dogs housed in three different environments were examined.
Rectal swabs were obtained from 85 dogs from households (26.2\%), 84 dogs from animal shelters (25.8\%), and 156 dogs from hunting kennels (48.0\%). Of the 325 sampled dogs, $140(43.1 \%)$ and 185 (56.9\%) were males and females, and 49 (15.1\%) and 276 (84.9\%) were puppies and adult dogs, respectively.

Regarding feeding, of the 325 dogs analysed, 196 ate commercial pet food (60.3\%), and the remaining dogs were also fed home-prepared food (39.7\%). Moreover, 36 dogs $(11.1 \%)$ were fed raw food. The type of water source was also asked in the questionnaire; 11 dogs (3.4\%) drank bottled water, while 269 (82.8\%) drank running water and $45(13.8 \%)$ drank from a water well. Finally, whether the dogs were in contact with other animal species was also asked in the questionnaire, and 178 dogs of 325 (54.8\%) were in contact with wild animals. Independent of the environment where dogs lived, only $6(1.85 \%)$ of the 325 rectal swabs analysed were positive for Salmonella spp. No significant differences were found between the percentage of Salmonella spp. and the age, sex, type of food, water source or contact with wild animals. However, the prevalence of Salmonella spp. was higher in animals that were fed raw food compared to those that did not eat raw food, and this difference was statistically significant ( $p$ value $\leq 0.01$ ).

Serotypes isolated from dog rectal samples are also shown in Table 1. Serotyping revealed 3 different serovars: $S$. Mikawasima $(n=2) ; S$. Havana $(n=3)$ and Monophasic $S$. Typhimurium $(n=1)$.

\section{Antimicrobial susceptibility of Salmonella isolates}

The antimicrobial susceptibility of Salmonella serotypes is shown in Table 2. All serotypes were susceptible to all antimicrobials tested except monophasic $S$. Typhimurium, which was resistant to ampicillin.

\section{Macroscopic LAB differences between Salmonella-positive and Salmonella-negative dogs}

LAB from Salmonella-negative dogs $(n=319)$ and Salmonella-positive dogs $(n=6)$ were grown on MRS agar. Macroscopic analysis was carried out, and subjective differences were observed. Figures 1 and 2 show the macroscopic profile of LAB from the Salmonella-negative and Salmonella-positive dogs, respectively. As an initial approximation, Salmonella-negative animals seemed to have more LAB than Salmonella-positive animals.

\section{Discussion}

Although dogs may not play as large of a role in the transmission of salmonellosis to people as food, dogs have long been known to be asymptomatic carriers of Salmonella serotypes [31]. Their close relationship and frequent contact with humans, especially children, may make these animals a potential source of Salmonella 
Table 1 The prevalence of Salmonella spp. in apparently healthy dogs and variables included in the study

\begin{tabular}{|c|c|c|c|c|c|}
\hline Variable Categories & & $\begin{array}{l}\text { No. of Dogs } \\
(\%)\end{array}$ & $\begin{array}{l}\text { No. positive for } \\
\text { Salmonella spp. }\end{array}$ & Salmonella Serotype (n) & X2 (p-value) \\
\hline \multirow[t]{3}{*}{ Dog population } & Households & $85(26.2)$ & 1 & S. Mikawasima (1) & $1.86(0.39)$ \\
\hline & $\begin{array}{l}\text { Animal } \\
\text { shelters }\end{array}$ & $84(25.8)$ & 3 & S. Havana (3) & \\
\hline & $\begin{array}{l}\text { Hunting } \\
\text { kennels }\end{array}$ & $156(48)$ & 2 & S. Mikawasima (1) Monophasic S. Typhimurium (1) & \\
\hline \multirow[t]{2}{*}{ Gender } & Males & $140(43.1)$ & 3 & $\begin{array}{l}\text { S. Mikawasima (1) S. Havana (1) Monophasic S. } \\
\text { Typhimurium (1) }\end{array}$ & $0.12(0.73)$ \\
\hline & Females & $185(56.9)$ & 3 & S. Mikawasima (1) S. Havana (2) & \\
\hline \multirow[t]{2}{*}{ Age } & Puppies & $49(15.1)$ & 2 & S. Havana (2) & $1.59(0.21)$ \\
\hline & Adults & $276(84.9)$ & 4 & $\begin{array}{l}\text { S. Mikawasima (2) S. Havana (1) Monophasic S. } \\
\text { Typhimurium (1) }\end{array}$ & \\
\hline \multirow[t]{2}{*}{ Diet } & Commercial & $196(60.3)$ & 3 & S. Havana (3) & $0.27(0.60)$ \\
\hline & $\begin{array}{l}\text { Home } \\
\text { prepared }\end{array}$ & $129(39.7)$ & 3 & S. Mikawasima (2) Monophasic S. Typhimurium (1) & \\
\hline \multirow{2}{*}{$\begin{array}{l}\text { Raw food } \\
\text { consumption }\end{array}$} & Yes & $36(11.1)$ & 4 & S. Havana (3) Monophasic S. Typhimurium (1) & $19.18(<0.01)^{*}$ \\
\hline & No & $289(88.9)$ & 2 & S. Mikawasima (2) & \\
\hline \multirow[t]{3}{*}{ Source of water } & Bottled water & $11(3.4)$ & 0 & - & $0.24(0.89)$ \\
\hline & $\begin{array}{l}\text { Running } \\
\text { water }\end{array}$ & $269(82.2)$ & 5 & $\begin{array}{l}\text { S. Mikawasima (1) S. Havana (3) Monophasic S. } \\
\text { Typhimurium (1) }\end{array}$ & \\
\hline & Well water & $45(13.8)$ & 1 & S. Mikawasima (1) & \\
\hline \multirow{2}{*}{$\begin{array}{l}\text { Contact with wild } \\
\text { animals }\end{array}$} & Yes & $178(54.8)$ & 2 & S. Mikawasima (1) Monophasic S. Typhimurium (1) & $1.13(0.29)$ \\
\hline & No & $147(45.2)$ & 4 & S. Mikawasima (1) S. Havana (3) & \\
\hline Overall & & $325(100)$ & 6 & & \\
\hline
\end{tabular}

${ }^{*} p$ value $\leq 0.01$ was considered significant

spp. for humans and thereby represent an important public health issue $[2,10,11,18]$.

The isolation of Salmonella spp. from clinically healthy dogs has been reported to be between 0 and $79 \%$ [11, $21,23,24,27]$. The results obtained in the present study showed a prevalence of Salmonella spp. of $1.8 \%$ in apparently healthy dogs in Valencian Region (Southern Spain). Our results were in accordance with the literature. In most studies, the prevalence of Salmonella-positive dogs was below 3\% [12]. Nevertheless, previous studies have shown that the prevalence of Salmonella in asymptomatic dogs can vary geographically $[10,11,18$, 19, 22, 23, 25]. Factors associated with these variations could be in part related to differences in the sample sizes, faecal sampling conditions and isolation and detection methods employed [11, 23]. In the present study, dogs were sampled only once. The low prevalence observed in our study could be related to the fact that only one faecal sample was collected, as intermittent shedding of Salmonella spp. has been well documented [11, 17]. However, rectal swab samples were employed in other studies to determine the presence of Salmonella in dog faeces; these studies observed similar results and a higher prevalence of Salmonella [32, 33].

The prevalence of Salmonella spp. in dogs has also been reported to depend on the immediate environment in which the animals live [11]. For example, the rates of isolating Salmonella from stray dogs have been reported to be significantly higher than those from household dogs [32]. In the current study, samples were collected from dogs housed in three different environments: households, animal shelters and hunting kennels. The

Table 2 Antimicrobial resistance of Salmonella spp. isolated from dog rectal samples

\begin{tabular}{|c|c|c|c|c|c|c|c|c|c|c|c|}
\hline \multirow{2}{*}{$\begin{array}{l}\text { Salmonella serotype (No. of } \\
\text { isolates) }\end{array}$} & \multicolumn{7}{|c|}{ Antimicrobial susceptibility } & \multirow[b]{2}{*}{ TGC } & \multirow[b]{2}{*}{ SXT } & \multirow[b]{2}{*}{ CT } & \multirow[b]{2}{*}{ C } \\
\hline & AMP & CTX & CAZ & GM & ND & CIP & $\overline{A Z M}$ & & & & \\
\hline S. Havana (3) & $S$ & S & S & $S$ & $S$ & S & S & $\mathrm{S}$ & $S$ & $S$ & $\bar{S}$ \\
\hline S. Mikawasima (2) & S & S & S & $S$ & S & S & S & S & $S$ & S & S \\
\hline Monophasic S. Typhimurium (1) & $\mathrm{R}$ & $S$ & S & $S$ & S & $S$ & S & $S$ & $S$ & S & $S$ \\
\hline
\end{tabular}

AMP Ampicillin, CTX Cefotaxime, CAZ Ceftazidime, GM Gentamicin, ND Nalidixic acid, CIP Ciprofloxacin, AZM Azithromycin, TGC Tigecycline, SXT Trimethoprimsulfamethoxazole, $C T$ Colistin, $C$ Chloramphenicol, $S$ Susceptible, $R$ Resistant 


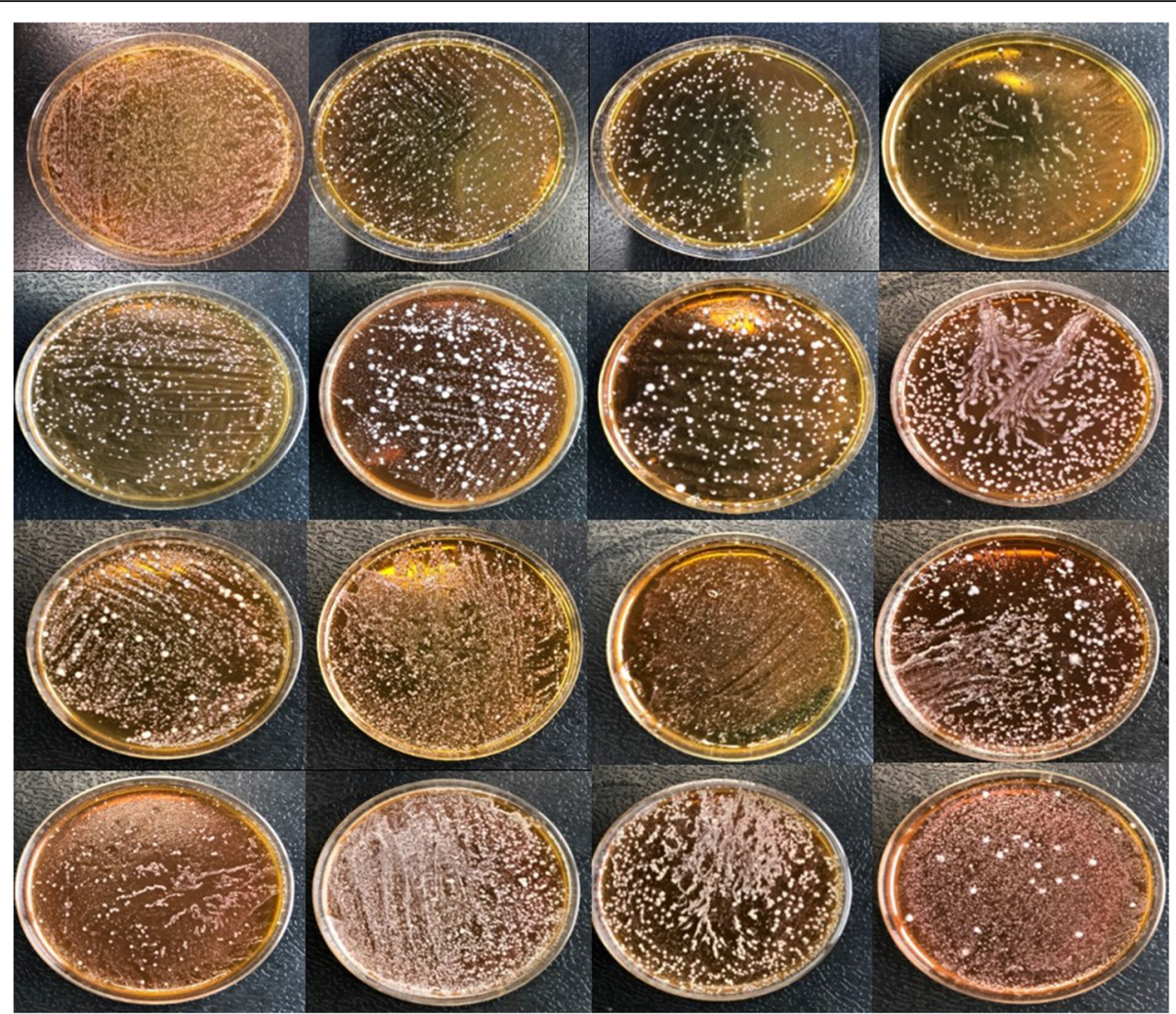

Fig. 1 Macroscopic image of $L A B$ from Salmonella spp.-negative dogs on MRS agar plates after $48 \mathrm{~h}$ of incubation at $37^{\circ} \mathrm{C}$ under anaerobic conditions

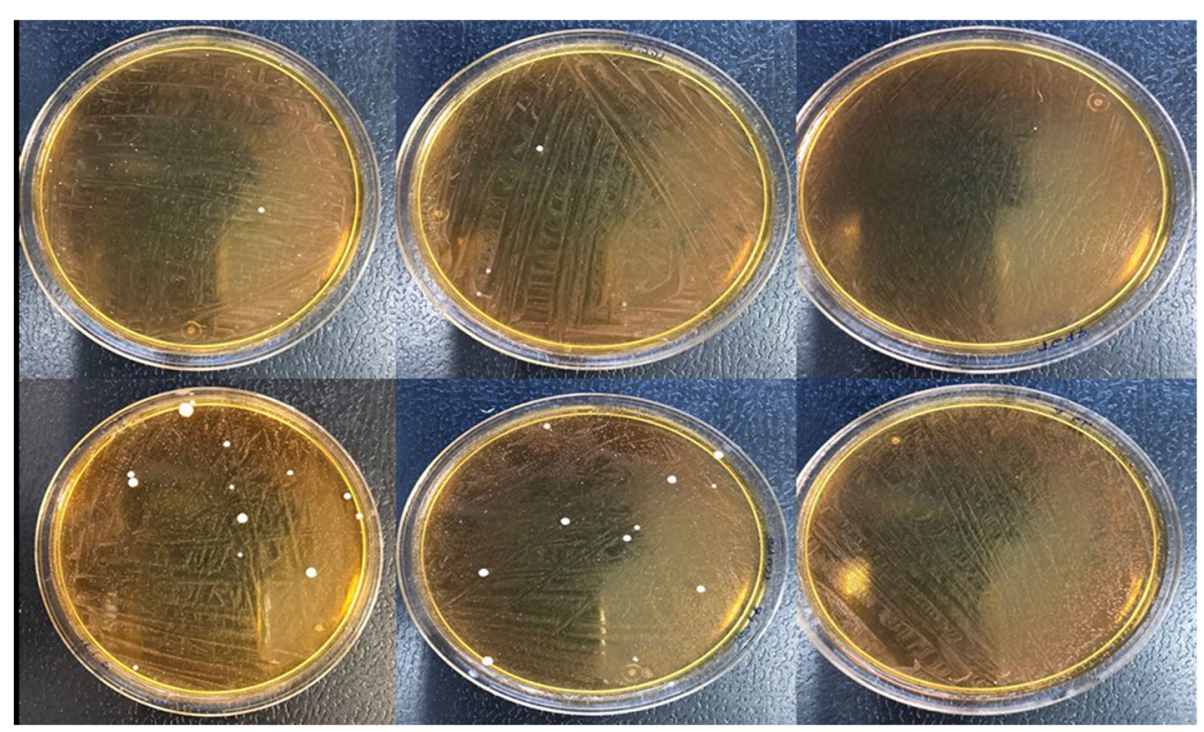

Fig. 2 Macroscopic image of LAB from Salmonella spp.-positive dogs on MRS agar plates after $48 \mathrm{~h}$ of incubation at $37^{\circ} \mathrm{C}$ under anaerobic conditions 
results of our study are in accordance with Reimschuessel et al. (2017) [12]. They found that there was no significant statistical association with Salmonella status and living or exposure with other animals, age, exposure to water sources, hunting or performing sport activities. However, different studies have shown that the prevalence of Salmonella in dogs exposed to contaminated environments including hunting dogs or stray dogs is higher than that in household dogs [12, 23, 32, 33]; this result could be because dogs are more likely to roam free, scavenge, be in contact with carcasses or offals of wildlife and be fed raw or undercooked food [23, 33, 34].

As mentioned, differences in the prevalence of Salmonella can also vary depending on feeding practices [11]. Feeding pet raw meat-based diets (RMBDs) has received increasing attention in recent years [35]. Our results showed that 4 of 6 dogs positive for Salmonella were fed raw poultry carcasses. These results are in accordance with other studies that concluded that consuming raw diets increases the risk of carrying Salmonella spp. [12, 20, 21, 24, 27, 36].

Different studies have recorded that serovars found more frequently in dog faeces are similar to those found in humans [10, 12, 22, 32, 36, 37]. In the present study, three serotypes were isolated, monophasic Salmonella Typhimurium (16.7\%), S. Havana (50\%) and S. Mikawasima (33.3\%), which have also been implicated in human salmonellosis [38-40]. All serotypes have been reported previously in dogs and humans [1, 16, 18, 39-45], and they have also been reported to be present in raw food $[1,39]$.

In our study, $S$. Havana were found in the faeces of Salmonella-positive dogs fed raw chicken carcasses. This serotype has been isolated previously from poultry products [46]. Pace et al. [38] determined a possible human infection caused by $S$. Havana from dog food contamination. S. Mikawasima has also been found in both wild boar from cattle-free and cattle-grazed areas in Spain [47], and in our study, S. Mikawasima was isolated from one hunting dog in contact with these species. Moreover, there has been an unusual increase in the number of $S$. Mikawasima infections in humans [39, 44]. Therefore, these results underline the potential public health risk of dog- and pet-contaminated foods [12, 22, 34].

In addition, a major problem in terms of both animal and human health is the emergence and increase in antibiotic resistance [34]. In fact, Salmonella has been listed by the World Health Organization (WHO) as one of the antibiotic-resistant priority pathogens and has become a worldwide health issue [48]. The results obtained in the present study showed that all serotypes isolated in our study were susceptible to all antibiotics tested. This is in accordance with other studies [11, 12, 49-51]. Only monophasic $S$. Typhimurium was resistant to ampicillin.
Other authors have reported the isolation of resistant Salmonella strains from dogs [11, 12, 32, 52]. In addition, adding raw animal products to pet dog diets has been identified as a risk factor for the presence of antimicrobial-resistant Salmonella spp. [11, 53].

New strategies are urgently needed to manage antimicrobial resistant infections [34, 48, 53]. Among the various methods to reduce the use of antibiotics [54], probiotics are expected to be an alternative intervention measure to prevent bacterial infection in dogs [55]. To identify beneficial probiotic bacteria that inhibit pathogens, a better understanding of the dog microbiome is needed [56-58]. As a preliminary approach, we compared LAB in samples from both Salmonella spp.-positive and Salmonella spp.-negative animals, and it seems that macroscopic differences were observed. Commensal bacteria maintain the stability of the digestive tract and can help prevent intestinal infections by modulating the immune response and inhibiting certain pathogens such as Salmonella spp. that cause infections [58, 59]. The subjective differences observed at the macroscopic level in our study could suggest that some LAB may protect against the pathogen or, on the other hand, the presence of Salmonella spp. in dogs could inhibit beneficial LAB strains. Our preliminary results could be in accordance with other studies that observed that gut LAB in pigs inhibit the growth of Salmonella and prevent the adhesion of bacteria in the intestinal tract [60].

In that sense, further studies must be carried out to address the limitations of our study and analyse whether these differences could be related to Salmonella spp. infection. It would be interesting to identify whether some species of LAB in Salmonella spp.-negative dogs are able to inhibit Salmonella spp., which could explain the absence of infection. Host species specificity is considered a requirement for probiotics, especially as a therapy for GI disorders [58]. In that sense, the study of dog microbiota may lead to the discovery of new therapies that can act against pathogens such as Salmonella spp.

\section{Conclusion}

In conclusion, the results obtained in this study indicate that apparently healthy dogs can act as subclinical carriers of Salmonella spp. in the Valencian region, eastern Spain. This could be significant to public health, as dogs are in close contact with humans. However, further studies must be performed because it is known that the shedding of Salmonella in dog faeces is influenced by several factors, such as diet, sampling procedures, and geographic area. Moreover, additional studies must be performed to determine the relationship between LAB and Salmonella spp. in dog faeces. 


\section{Methods}

\section{Sample collection and questionnaire}

All animals were handled according to the principles of animal care published by Spanish Royal Decree 53/2013 [61]. Sample collection was carried out in the Valencian Region (eastern Spain) between October 2017 and June 2018. A total of 325 healthy dogs housed in three different environments were sampled (dogs were housed in households or animal shelters or were hunting dogs). Rectal specimens were collected using sterile cotton swabs (Cary Blair sterile transport swabs, Deltalab, Barcelona, Spain) by rotating the swab inside the rectum of the dog and then transported under refrigeration to the Laboratory of "Agentes microbiológicos asociados a la Reproducción Animal-ProVaginBIO”, UCH-CEU University, for Salmonella spp. isolation.

Data from each dog were also collected by a questionnaire developed for this study (Additional file 1) to determine the possible risk factors for Salmonella spp. infection, especially those related to the environment where animals were housed, the diet or type of food, contact with other animal species and the source of water. Other data were also included in this questionnaire, including gender and age. All questionnaires were completed and submitted together with the samples to the laboratory.

Salmonella spp. isolation, serotyping and determination of antibiotic susceptibility.

Salmonella isolation was performed according to ISO 6579: 2002 (Annex D) [62]. First, samples were preenriched for $18 \pm 2 \mathrm{~h}$ at $37{ }^{\circ} \mathrm{C} \pm 1{ }^{\circ} \mathrm{C}$ in $1: 10 \mathrm{vol} / \mathrm{vol}$ buffered peptone water 2.5\% (BPW; Scharlau, Barcelona, Spain). Then, $0.1 \mathrm{~mL}$ of the preenriched sample was transferred onto Semi-Solid Modification Rappaport Vassiliadis agar plates (MSRV; Difco, Valencia, Spain) and incubated at $41.5^{\circ} \mathrm{C} \pm 1{ }^{\circ} \mathrm{C}$ for $24-48 \mathrm{~h}$. Suspicious growth on these plates was selected for inoculation onto Xylose-LysineDeoxycholate (XLD; Liofilchem, Valencia, Spain) and ASAP (ASAP, bioMerieux, Madrid, Spain) agar plates, which were incubated at $37^{\circ} \mathrm{C} \pm 1{ }^{\circ} \mathrm{C}$ for $24-48 \mathrm{~h}$. After the incubation period, presumptive Salmonella colonies were selected, streaked onto nutrient agar plates (Scharlab, Barcelona, Spain) and incubated at $37^{\circ} \mathrm{C} \pm 1{ }^{\circ} \mathrm{C}$ for $24 \pm 3 \mathrm{~h}$. Then, a biochemical test using API (API-20, bioMerieux, Madrid, Spain) was performed to confirm the presence of Salmonella spp. Moreover, Salmonella isolates were serotyped by the Ministry of Agriculture, Fisheries and Food Reference Laboratory (Algete, Madrid, Spain) according to the Kauffman-White-Le Minor scheme.

The antibiotics selected to test Salmonella spp. antimicrobial susceptibility were those set forth in Decision 2013/653 [63]: ampicillin $(10 \mu \mathrm{g})$, cefotaxime $(30 \mu \mathrm{g})$, ceftazidime $(30 \mu \mathrm{g})$, gentamicin $(10 \mu \mathrm{g})$, nalidixic acid
$(30 \mu \mathrm{g})$, ciprofloxacin $(5 \mu \mathrm{g})$, azithromycin $(15 \mu \mathrm{g})$, tigecycline $(15 \mu \mathrm{g})$, trimethoprim-sulfamethoxazole $(25 \mu \mathrm{g})$, colistin $(10 \mu \mathrm{g})$ and chloramphenicol $(5 \mu \mathrm{g})$. Antimicrobial susceptibility was tested according the European Committee on Antimicrobial Susceptibility Testing (EUCAST) guidelines [64]. The source for zone diameters used for interpretation of the test was http://www. eucast.org/clinical_breakpoints/. Zone diameters were interpreted and categorized as susceptible, intermediate or resistant according to the EUCAST clinical breakpoint tables.

\section{Lactic acid bacteria isolation}

LAB isolation was carried out using the same rectal samples collected for Salmonella spp. isolation. Swabs were homogenized in BPW, and $100 \mu \mathrm{l}$ was inoculated in the medium used for identification of LAB, especially Lactobacillus Man, Rogosa and Sharpe (MRS agar) (Scharlab, Barcelona, Spain) $[65,66]$, and incubated for 24-48 h under anaerobic conditions. After incubation, subjective macroscopic observation was carried out.

\section{Statistical analysis}

Statistical analysis was performed with the statistical package $\mathrm{R}$ Commander and RcmdrPlugin. The associations between Salmonella occurrence; categorical factors were compared using Pearson's $\chi^{2}$ test, and the confidence intervals for prevalence estimates were calculated using the Wilson score interval method. A $p$-value < 0.01 was reported as statistically significant.

\section{Supplementary information}

Supplementary information accompanies this paper at https://doi.org/10. 1186/s12917-020-02492-3.

Additional file 1. Questionnaire

\section{Abbreviations}

ASAP: Chromogenic Culture Media for Rapid Salmonella Detection; BPW: Buffered Peptone Water; LAB: Lactic Acid Bacteria; MRS: Man Rogosa Sharpe; MSRV: Semisolid Modification Rappaport Vassiliadis; XLD: XyloseLysine-Deoxycholate

\section{Acknowledgements}

We would like to thank the animal shelters and dog owners for their cooperation during sample collection.

\section{Authors' contributions}

EJT and EB contributed to the study design, laboratory investigation and preparation of the draft manuscript. EGR provided technical assistance during laboratory investigation. VL was involved in sample collection. LLI participated in the data analysis. All authors read and approved the final manuscript.

\section{Funding}

This work was funded by the precompetitive projects CEU - Banco santander (FUSP-BS-PPC15/2016). The funding agency was not involved in design of study, data collection, analysis of data and manuscript writing. 


\section{Availability of data and materials}

The datasets analysed during this study are available from the corresponding author on reasonable request.

\section{Ethics approval and consent to participate}

This work was approved by the precompetitive projects CEU - Banco Santander (FUSP-BS-PPC15/2016). All animals were handled according to the principles of animal care published by Spanish Royal Decree 53/2013 (Official Spanish State Gazette [BOE], 2013). Sampled collection was approved by the Ethics Committee and Animal Experimentation of UCH-CEU University. Informed oral consent, also approved by the Ethics Committee and Animal Experimentation of the UCH-CEU University, was obtained from the dog owners and shelters at the time of sample collection. Consent was documented in the questionnaire that owners and shelters also completed at the time of sample collection.

\section{Consent for publication}

Not applicable.

\section{Competing interests}

The authors declare that they have no competing interests.

\section{Author details}

${ }^{1}$ Research Group Microbiological Agents Associated with Animal Reproduction (PROVAGINBIO), Department of Animal Production and Health, Veterinary Public Health and Food Science and Technology (PASAPTA), Facultad de Veterinaria, Universidad Cardenal Herrera-CEU, CEU Universities, Carrer Tirant lo Blanc 7, 46115 Alfara del Patriarca, València, Spain. ${ }^{2}$ Grupo Sanidad de Rumiantes, Facultad de Veterinaria, Universidad de Murcia, C/ Campus Universitario 7, 30100 Murcia, Spain. ${ }^{3}$ Servicio de Análisis, Investigación, Gestión de Animales Silvestres (SAIGAS), Facultad de Veterinaria, Universidad Cardenal Herrera-CEU, CEU Universities, C/Tirant lo Blanc 7, 46115 Alfara del Patriarca, Valencia, Spain. ${ }^{4}$ Wildlife Ecology \& Health group (WE\&H), Universitat Autònoma de Barcelona (UAB), Edifici V, Travessera del Turons, 08193 Bellaterra, Barcelona, Spain.

\section{Received: 8 October 2019 Accepted: 27 July 2020}

\section{Published online: 03 August 2020}

\section{References}

1. EFSA, ECDC. The European Union summary report on trends and sources of zoonoses, zoonotic agents and foodborne outbreaks in 2017. 2018. https:// efsa.onlinelibrary.wiley.com/doi/epdf/10.2903/j.efsa.2018.5500. Accessed 16 Sept 2019.

2. Sato $Y$, Mori T, Koyama T, Nagase H. Salmonella Virchow infection in an infant transmitted by household dogs. J Vet Med Sci. 2000;62:767-9.

3. Finlay F, Furnell C, Ridley P. Salmonella in pets: the risk to children. Community Pract. 2015:88:27-8.

4. Damborg P, Broens EM, Chomel BB, Guenther S, Pasmans F, Wagenaar JA, Weese JS, Wieler LH, Windahl U, Vanrompay D, Guardabassi L. Bacterial zoonoses transmitted by household pets: state-of-the-art and future perspectives for targeted research and policy actions. J Comp Pathol. 2016; 155:S27-40.

5. Anderson TC, Marsden-Haug N, Morris JF, Culpepper W, Bessette N, Adams JK, Bidol S, Meyer S, Schmitz J, Erdman MM, Gomez TM, Barton BC. Multistate outbreak of human Salmonella Typhimurium infections linked to pet hedgehogs - United States, 2011-2013. Zoonoses Public Health. 2017;64: 290-8.

6. Bruce HL, Barrow PA, Rycroft AN. Zoonotic potential of Salmonella enterica carried by pet tortoises. Vet Rec. 2018;182:141.

7. Westgarth C, Pinchbeck GL, Bradshaw JW, Dawson S, Gaskell RM, Christley RM. Factors associated with dog ownership and contact withdogs in a UK community. BMC Vet Res. 2017;3:5.

8. MAGRAMA. 2015. https://www.mapa.gob.es/es/ganaderia/temas/ produccion-y-mercados-ganaderos/20160222_informeestudioparapublicar tcm30-104720.pdf Accessed 24 May 2019.

9. Behravesh CB, Ferraro A, Deasy M, Dato V, Moll M, Sandt C, Rea NK, Rickert R, Marriott C, Warren K, Urdaneta V, Salehi E, Villamil E, Ayers T, Hoekstra RM, Austin JL, Ostroff S, Williams IT. Human Salmonella infections linked to contaminated dry dog and cat food, 2006-2008. Pediatrics. 2010;126:47783.
10. Leonard F. Salmonella infection and carriage: the importance of dogs and their owners. Vet Rec. 2014;174:92-3.

11. Lowden $\mathrm{P}$, Wallis C, Gee N, Hilton A. Investigating the prevalence of Salmonella in dogs within the midlands region of the United Kingdom. BMC Vet Res. 2015;17:11-239.

12. Reimschuessel R, Grabenstein M, Guag J, Nemser SM, Song K, Qiu J, Clothier KA, Byrne BA, Marks SL, Cadmus K, Pabilonia K, Sanchez S, Rajeev S, Ensley S, Frana TS, Jergens AE, Chappell KH, Thakur S, Byrum B, Cui J, Zhang Y, Erdman MM, Rankin SC, Daly R, Das S, Ruesch L, Lawhon SD, Zhang S, Baszler T, Diaz-Campos D, Hartmann F, Okwumabua O. Multilaboratory survey to evaluate Salmonella prevalence in diarrheic and nondiarrheic dogs and cats in the United States between 2012 and 2014. J Clin Microbiol. 2017:55:1350-68.

13. Wright JG, Tengelsen LA, Smith KE, Bender JB, Frank RK, Grendon JH, Rice $\mathrm{DH}$, Thiessen AM, Gilbertson CJ, Sivapalasingam S, Barrett TJ, Besser TE, Hancock DD, Angulo FJ. Multidrug-resistant Salmonella Typhimurium in four animal facilities. Emerg Infect Dis. 2005;11:1235-41.

14. Hoelzer K, Moreno Switt Al, Wiedmann M. Animal contact as a source of human non-typhoidal salmonellosis. Vet Res. 2011;42:34.

15. Stull JW, Peregrine AS, Sargeant JM, Weese JS. Pet husbandry and infection control practices related to zoonotic disease risks in Ontario, Canada. BMC Public Health. 2013;13:520.

16. Morse EV, Duncan MA, Estep DA, Riggs WA, Blackburn BO. Canine salmonellosis: a review and report of dog to child transmission of Salmonella enteritidis. Am J Public Health. 1976;66:82-3.

17. Mackel DC, Galton MM, Gray H, Hardy AV. Salmonellosis in dogs. IV prevalence in normal dogs and their contacts. J Infect Dis. 1952;91:15-8.

18. Carter ME, Quinn JP. Salmonella infections in dogs and cats. In: Wray C, Wray A, editors. Salmonella in domestic animals. Wallingford: CAB International; 2000. p. 231-44.

19. Timbs DV, Davies GB, Carter ME, Carman MG. The Salmonella excretor incidence of dogs in Hawke's bay. N Z Vet J. 1975;23:54-6.

20. Chengappa MM, Staats J, Oberst RD, Gabbert NH, McVey S. Prevalence of Salmonella in raw meat used in diets of racing greyhounds. J Vet Diagn Investig. 1993;5:372-7.

21. Cantor GH, Nelson S, Vanek JA, Evermann JF, Eriks IS, Basaraba RJ, Besser TE. Salmonella shedding in racing sled dogs. J Vet Diagn Investig. 1997;9:447-8.

22. Sanchez S, Hofacre CL, Lee MD, Maurer JJ, Doyle MP. Animal sources of salmonellosis in humans. J Am Vet Med Assoc. 2002;221:492-7.

23. Seepersadsingh $N$, Adesiyun AA, Seebaransingh R. Prevalence and antimicrobial resistance of Salmonella spp. in non-diarrhoeic dogs in Trinidad. J. Vet med. B. Infect. Dis. Vet. Public Health. 2004;51:337-42.

24. McKenzie E, Riehl J, Banse H, Kass PH, Nelson S Jr, Marks SL. Prevalence of diarrhea and enteropathogens in racing sled dogs. J Vet Intern Med. 2010;24:97-103.

25. Marks SL, Rankin SC, Byrne BA, Weese JS. Enteropathogenic bacteria in dogs and cats: diagnosis, epidemiology, treatment, and control. J Vet Intern Med. 2011;25:1195-208

26. Liebana E, Garcia-Migura L, Clouting C, Clifton-Hadley FA, Lindsay E, Threlfall EJ, McDowell SW, Davies RH. Multiple genetic typing of Salmonella enterica serotype Typhimurium isolates of different phage types (DT104, U302, DT204b, and DT49) from animals and humans in England, Wales, and Northern Ireland. J Clin Microbiol. 2002;40:4450-6.

27. Finley R, Ribble C, Aramini J, Vandermeer M, Popa M, Litman M, Reid-Smith $R$. The risk of salmonellae shedding by dogs fed Salmonella-contaminated commercial raw food diets. Can Vet J. 2007;48:69-75.

28. Davies RH, Lawes JR, Wales AD. Raw diets for dogs and cats: a review, with particular reference to microbiological hazards. J Small Anim Pract. 2019;60:329-39.

29. Suchodolski JS. Intestinal microbiota of dogs and cats: a bigger world than we thought. Vet Clin North Am Small Anim Pract. 2011;41:261-72.

30. Ng KM, Ferreyra JA, Higginbottom SK, Lynch JB, Kashyap PC, Gopinath S, Naidu N, Choudhury B, Weimer BC, Monack DM, Sonnenburg JL. Microbiota-liberated host sugars facilitate post-antibiotic expansion of enteric pathogens. Nature. 2013;502:96-9.

31. Morse EV, Duncan MA. Canine salmonellosis: prevalence, epizootiology, signs and public health significance. J Am Vet Med Assoc. 1975;167:817-20.

32. Tsai HJ, Huang HC, Lin CM, Lien YY, Chou CH. Salmonella and campylobacters in household and stray dogs in northern Taiwan. Vet Res Comm. 2007;31:931-9.

33. Jajere SM, Onyilokwu SA, Adamu NB, Atsanda NN, Saidu AS, Adamu SG, Mustapha FB. Prevalence of Salmonella infection in dogs in Maiduguri, northeastern Nigeria. Int J Microbiol. 2014;2014:392548. 
34. Van Bree FPJ, Bokken GCAM, Mineur R, Franssen F, Opsteegh M, van der Giessen JWB, Lipman LJA, Overgaauw PAM. Zoonotic bacteria and parasites found in raw meat-based diets for cats and dogs. Vet Rec. 2018;182:50.

35. Fredriksson-Ahomaa M, Heikkilä T, Pernu N, Kovanen S, Hielm-Björkman A, Kivistö R. Raw meat-based diets in dogs and cats. Vet Sci. 2017;28:4.

36. Lefebvre SL, Reid-Smith R, Boerlin P, Weese JS. Evaluation of the risks of shedding Salmonellae and other potential pathogens by therapy dogs fed raw diets in Ontario and Alberta. Zoonoses Public Health. 2008:55:470-80.

37. Simpson KMJ, Hill-Cawthorne GA, Ward MP, Mor SM. Diversity of Salmonella serotypes from humans, food, domestic animals and wildlife in New South Wales, Australia. BMC Infect Dis. 2018;18:623.

38. Pace PJ, Silver KJ, Wisniewski HJ. Salmonella in commercially produced dried dog food: possible relationship to a human infection caused by Salmonella enteritidis serotype Havana. J Food Prot. 1977;40:317-21.

39. EFSA and ECDC. Unusual increase of Salmonella Mikawasima infections in humans. EFSA supporting publication 2013: EN-5112; 2013. p. 9. https://doi. org/10.2903/sp.efsa.2013.EN-512. https://efsa.onlinelibrary.wiley.com/doi/ abs/10.2903/sp.efsa.2013.EN-512 Accessed 16 Sept 2019.

40. Ikeda JS, Hirsh DC, Jang SS, Biberstein E. Characteristics of Salmonella isolated from animals at a veterinary medical teaching hospital. Am J Vet Res. 1986:47:232-5.

41. Philbey AW, Mather HA, Gibbons JF, Thompson H, Taylor DJ, Coia JE. Serovars, bacteriophage types and antimicrobial sensitivities associated with salmonellosis in dogs in the UK (1954-2012). Vet Rec. 2014;174:94.

42. Kiflu B, Alemayehu $H$, Abdurahaman M, Negash Y, Equale T. Salmonella serotypes and their antimicrobial susceptibility in apparently healthy dogs in Addis Ababa Ethiopia. BMC Vet Res. 2017;13:1-9.

43. Srisanga S, Angkititrakul S, Sringam P, Ho PT, Vo AT, Chuanchuen R. Phenotypic and genotypic antimicrobial resistance and virulence genes of Salmonella enterica isolated from pet dogs and cats. J Vet Sci. 2016;18:27381

44. Myšková P, Karpišková R. Unusual occurrence of Salmonella Mikawasima in 2012-2013 in the Czech Republic: part of a multistate outbreak? Pol J Microbiol. 2014;63:355-7.

45. Sakazaki R, Nakaya R. Epidemiological and ecological studies on Salmonelleae in Japan. End Dis Bull Nagasaki Univ. 1964:6:167-73.

46. Antunes P, Mourão J, Campos J, Peixe L. Salmonellosis: the role of poultry meat. Clin Microbiol Infect. 2016;22:110-21.

47. Navarro-Gonzalez N, Mentaberre G, Porrero CM, Serrano E, Mateos A, LópezMartín JM, Lavín S, Domínguez L. Effect of cattle on Salmonella carriage, diversity and antimicrobial resistance in free-ranging wild boar (Sus scrofa) in northeastern Spain. PLoS One. 2012;7:e51614.

48. World Health Organization (WHO). Prioritization of pathogens to guide discovery, research and development of new antibiotics for drug-resistant bacterial infections including tuberculosis. Geneva: World Health Organization; 2017. (WHO/EMP/IAU/2017.12). https://www.who.int/ medicines/areas/rational_use/PPLreport_2017_09_19.pdf?ua=1 Accessed 17 May 2019.

49. Selmi M, Stefanelli S, Bilei S, Tolli R, Bertolotti L, Marconi P, Giurlani S, De Lucia PG, Ruggeri G, Pagani A. Contaminated commercial dehydrated food as source of multiple Salmonella serotypes outbreak in a municipal kennel in Tuscany. Vet Ital. 2011:47:183-90.

50. Leonard EK, Pearl DL, Finley RL, Janecko N, Reid-Smith RJ, Peregrine AS, Weese JS. Comparison of antimicrobial resistance patterns of Salmonella spp. and Escherichia coli recovered from pet dogs from volunteer households in Ontario (2005-06). J Antimicrob Chemother. 2012;67:174-81.

51. Jay-Russell MT, Hake AF, Bengson Y, Thiptara A, Nguyen T. Prevalence and characterization of Escherichia coli and Salmonella strains isolated from stray dog and coyote feces in a major leafy greens production region at the United States-Mexico border. PLoS One. 2014;9:e113433.

52. Ojo OE, Adetosoye Al. Salmonella Typhimurium infection in diarrhoeic and non-diarrhoiec dogs in Ibadan, Nigeria. Veterinarski Arhiv. 2009;79:371-7.

53. Finley R, Reid-Smith R, Ribble C, Popa M, Vandermeer M, Aramini J. The occurrence and antimicrobial susceptibility of salmonellae isolated from commercially available canine raw food diets in three Canadian cities. Zoonoses Public Health. 2008:55:462-9.

54. Czaplewski L, Bax R, Clokie M, Dawson M, Fairhead H, Fischetti VA, Foster S, Gilmore BF, Hancock RE, Harper D, Henderson IR, Hilpert K, Jones BV Kadioglu A, Knowles D, Ólafsdóttir S, Payne D, Projan S, Shaunak S, Silverman J, Thomas CM, Trust TJ, Warn P, Rex JH. Alternatives to antibioticsa pipeline portfolio review. Lancet Infect Dis. 2016;16:239-51.
55. Masuoka H, Shimada K, Kiyosue-Yasuda T, Kiyosue M, Oishi Y, Kimura S, Yamada A, Hirayama K. Transition of the intestinal microbiota of dogs with age. Biosci Microbiota Food Health. 2017;36:27-31.

56. Grześkowiak $Ł$, Endo A, Beasley S, Salminen S. Microbiota and probiotics in canine and feline welfare. Anaerobe. 2015;34:14-23.

57. Schmitz S, Suchodolski J. Understanding the canine intestinal microbiota and its modification by pro-, pre- and synbiotics - what is the evidence? Vet Med Sci. 2016;2:71-94.

58. Kumar S, Pattanaik AK, Sharma S, Jadhav SE, Dutta N, Kumar A. Probiotic. Potencial of a Lactobacillus bacterium of canine Faecal-origin and its impact and select gut health indices and Inmune response of dogs. Probiotics Antimicrob Proteins. 2017;9:262-77

59. Kore KB, Patil SS, Phondaba BT. Gastrointestinal microbial ecology and its health benefits in dogs. Vet World. 2010;3:140-1.

60. Casey PG, Casey GD, Gardiner GE, Tangney M, Stanton C, Ross RP, Hill C, Fitzgerald GF. Isolation and characterization of anti-Salmonella lactic acid bacteria from the porcine gastrointestinal tract. Lett Appl Microbiol. 2004;39: 431-8.

61. Spanish Royal Decree 53/2013. Real Decreto 53/2013, de 1 de febrero, por el que se establecen las normas básicas aplicables para la protección de los animales utilizados en experimentación y otros fines científicos, incluyendo la docencia. 2013. BOE-A-2013-1337. https://www.boe.es/buscar/pdf/2013/ BOE-A-2013-1337-consolidado.pdf Accessed 24 May 2019.

62. ISO 6579:2002 (Annex D): Anonymous. Microbiology of food and animal feeding stuffs. Horizontal method for the detection of Salmonella spp. International Organization for Standardization, Geneve, Switzerland. https:// www.iso.org/standard/29315.html Accessed 24 May 2019.

63. European Union, Commission implementing decision 2013/653 of 12 November 2013 as regards a Union financial aid towards a coordinated control plan for antimicrobial resistance monitoring in zoonotic agents in 2014 (notified under document C (2013) 7289), (2013.

64. Matuschek E, Brown DF, Kahlmeter G. Development of the EUCAST disk diffusion antimicrobial susceptibility testing method and its implementation in routine microbiology laboratories. Clin Microbiol Infect. 2014;20:0255-66.

65. Reuter G. Efective and selective media for lactic acid bacteria. Int J Food Microbiol. 1985;2:55-6.

66. Menconi A, Kallapura G, Latorre JD, Morgan MJ, Pumford NR, Hargis BM Tellez G. Identification and characterization of lactic acid Bateria in a commercial probiotic culture. Biosci Microbiota Food Health. 2014;33:25-30.

\section{Publisher's Note}

Springer Nature remains neutral with regard to jurisdictional claims in published maps and institutional affiliations.

Ready to submit your research? Choose BMC and benefit from:

- fast, convenient online submission

- thorough peer review by experienced researchers in your field

- rapid publication on acceptance

- support for research data, including large and complex data types

- gold Open Access which fosters wider collaboration and increased citations

- maximum visibility for your research: over $100 \mathrm{M}$ website views per year

At $\mathrm{BMC}$, research is always in progress.

Learn more biomedcentral.com/submission 